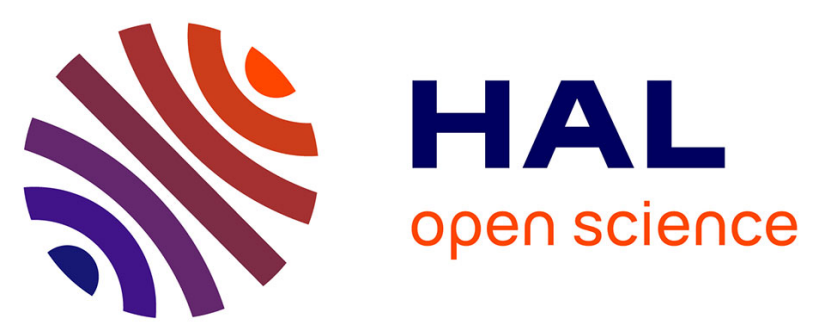

\title{
Impacts of long-term waste-water irrigation on the development of sandy Luvisols: consequences for metal pollutant distributions
}

\author{
Folkert F. van Oort, Antonius G. Jongmans, Isabelle Lamy, Denis Baize, \\ Pierre Chevallier
}

\section{To cite this version:}

Folkert F. van Oort, Antonius G. Jongmans, Isabelle Lamy, Denis Baize, Pierre Chevallier. Impacts of long-term waste-water irrigation on the development of sandy Luvisols: consequences for metal pollutant distributions. European Journal of Soil Science, 2008, 59 (5), pp.925-938. 10.1111/j.13652389.2008.01047.x . hal-02668319

\section{HAL Id: hal-02668319 \\ https://hal.inrae.fr/hal-02668319}

Submitted on 31 May 2020

HAL is a multi-disciplinary open access archive for the deposit and dissemination of scientific research documents, whether they are published or not. The documents may come from teaching and research institutions in France or abroad, or from public or private research centers.
L'archive ouverte pluridisciplinaire HAL, est destinée au dépôt et à la diffusion de documents scientifiques de niveau recherche, publiés ou non, émanant des établissements d'enseignement et de recherche français ou étrangers, des laboratoires publics ou privés. 


\title{
Impacts of long-term waste-water irrigation on the development of sandy Luvisols: consequences for metal pollutant distributions
}

\author{
F. VAN OORT ${ }^{\mathrm{a}}$, A. G. JONGMANS ${ }^{\mathrm{b}}$, I. LAMY ${ }^{\mathrm{a}}$, D. BAIZE ${ }^{\mathrm{c}}$ \& P. CheVAllier ${ }^{\mathrm{d}}$ \\ a INRA, UR 251 PESSAC, RD 10, F-78026 Versailles Cedex, France, ${ }^{\mathrm{b}}$ WUR, Wageningen University, Landscape Centre, PO Box 47, \\ 6700 AA, Wageningen, the Netherlands, 'INRA, UR 272, Unité de Science du Sol, BP 20619 Ardon, F-45166 Olivet Cedex, France, \\ and ${ }^{\mathrm{d}}$ CEA-CNRS, Laboratoire Pierre Suë, Bâtiment 637, F-91191 Gif-sur-Yvette Cedex, France
}

\begin{abstract}
Summary
Studies relating macro- and microscopic aspects of impacts of long-term contaminative practices on soils are scarce. We performed such an approach by assessing the fate of metal pollutants in an area close to Paris, where sandy Luvisols were irrigated for 100 years with urban waste water. As a result, these soils display strong accumulation of organic matter, dissolved salts and metal pollutants in surface horizons, but also migration of metals to depth. We examined soil development and metal distribution patterns in two irrigated soils, in comparison with a non-irrigated reference soil. Soil macromorphological characteristics were studied in the field. Soil micromorphology and micro-scale metal distributions were both studied in situ in thin sections, the latter by synchrotron X-ray mapping. Microscopic study focussed on characteristic parts of the Ap and Bt horizons, mainly involved in metal retention. For Ap horizons, both large and diffuse metal concentrations were revealed, mainly associated with organic matter and dissolved components added by irrigation water. For Bt horizons, zinc accumulation was detected on clay-iron coatings. Our results suggest that with time, a double metal-filtering capacity has developed in these sandy Luvisols: in the Ap horizon, an anthropogenic filter resulted from input of metal pollutants together with highly reactive organic matter, carbonates and phosphates, thus favouring metal immobilization and limiting migration to depth. In the Bt horizon, the evidence is of a second, natural filter. However, this filtering capacity is endangered by clay destruction due to ferrolysis, as revealed by micromorphology. Ferrolysis, here initiated by intensive irrigation practices, leads to a reduction of the natural filtering potential and an increasing risk of metal transfer towards the groundwater.
\end{abstract}

\section{Introduction}

Land management and agricultural practices greatly influence soil quality via soil organic matter (SOM) dynamics, soil biota, and soil structure (Droogers et al., 1996; Six et al., 1998). Long-term contaminative land practices such as the intensive use of fungicides were shown to lead to the development of different soil profiles within one soil series (Jongmans et al., 2001, 2003). Currently, information about relations between changes in macro- and microscopic soil characteristics and the fate of metal pollutants is scarce. Long-term irrigation of agricultural land with waste water is an example of land use that may strongly impact on soil quality and development. The use of urban waste water for irrigation is a worldwide practice, driven by different agronomic or environmental motives, i.e.

Correspondence: F. van Oort. E-mail: vanoort@versailles.inra.fr Received 27 April 2007; revised version accepted 10 March 2008 water-shortage, fertilizing effects, low-cost filtering of waste water and, at the same time, production of water-demanding crops. The benefit of such an approach for agricultural purposes is generally accepted, but the quality of waste water has widely declined over the second half of the 20th century, especially in many western countries (Cebula, 1980). In view of this, many studies have stressed major environmental risks related to waste water irrigation of agricultural crops, risks caused by an increasing amount of mineral and organic pollutants present in soils and in crops (Flores et al., 1997; Haiyan \& Stuantes, 2003).

In France, urban waste water generated by the western Paris agglomeration has been recycled since the end of the 19th century, before re-entering the hydrological network. For this purpose, thousands of hectares close to Paris, mainly composed of extensively used coarse-textured alluvial soils and sandy Luvisols, were irrigated, either for intensive dissipation of waste 
water (especially bare or fallow land) or for agricultural production (mainly food crops and maize). The economic benefit was noted as early as the 1890 s by an appreciable increase of productivity of these sandy soils for food crops (Risler, 1897). For about 100 years, huge amounts of waste water, with mean annual rates estimated at approximately 2000 litre $\mathrm{m}^{-2}$ (Védry et al., 2001) percolated through these soils. There is no doubt about the efficiency of the filtering function of these soils when observing today the thick (up to $60 \mathrm{~cm}$ ), sticky, black to darkbrown, clearly anthropogenic surface horizons in these sandytextured soils, due to the accumulation of large amounts of fine organic matter and dissolved mineral components (Baize et al., 2002; Lamy et al., 2006). Particularly since the second half of the 20th century, large amounts of organic and metal pollutants also were added via the waste water and accumulated predominantly in the surface horizons. Nevertheless, evidence was found for migration to depth of metal pollutants, in particular $\mathrm{Zn}$ and $\mathrm{Cd}$, and for their interception and accumulation in the illuvial Bt horizons (Dère et al., 2006, 2007; Lamy et al., 2006). However, the interception of $\mathrm{Zn}$ and $\mathrm{Cd}$ in clayey $\mathrm{B}$ horizons was not systematically observed in all waste-water irrigated soils (Lamy et al., 2006). Therefore, several questions arose regarding: (i) the different associations between metal pollutants and soil constituents governing metal retention in the surface and in deeper soil horizons, and (ii) the various potential effects of long-term intensive land use on soil characteristics and development.

The aim of the present work was to assess impacts of longterm irrigation with urban waste water on agricultural land in terms of soil composition and fabrics, and to relate them to metal microscale distribution patterns. To this end, we compared two Luvisol profiles under long-term, waste-water irrigation with a non-irrigated reference soil of the same Luvisol. Microscale distribution patterns of metal pollutants on selected soil constituents and micro-structures were studied by elemental mapping in undisturbed soil thin sections by means of synchrotron facilitated micro-fluorescence ( $\mu$-SXRF). The elemental correlations obtained were used to provide insight into metal pollutant incorporation dynamics, i.e. characteristic interactions between metal pollutants and soil constituents and/or microfabrics.

\section{Materials and methods}

\section{Site description}

The study site is located in the north-eastern part of an approximately 1200-ha area (Pierrelaye-Bessancourt) of polluted waste water irrigated market garden agrosystems (Figure 1). The geological substratum is a hard Lutetian limestone and covered by a Quaternary deposit of wind-borne quartzose sand mixed with lime particles (Baize et al., 2002). The soils are dominantly sandy Luvisols (FAO-UNESCO-ISRIC, 1988), occurring on a gently sloping plateau location. Pedogenesis started with complete carbonate dissolution down to about $80 \mathrm{~cm}$, fol-
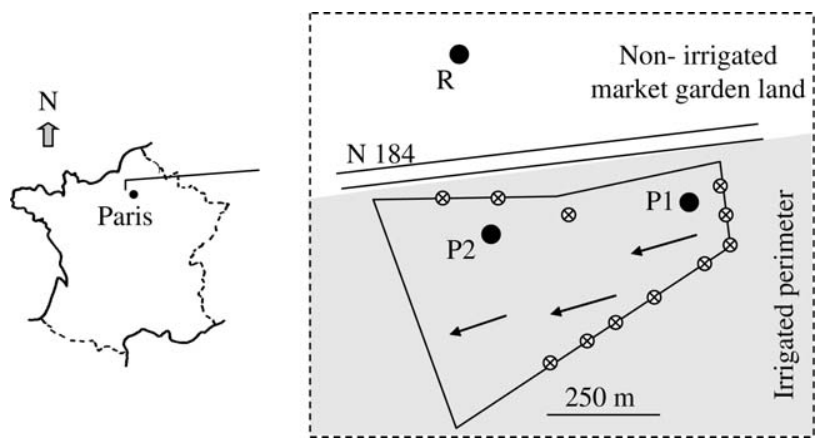

Figure 1 Location of the waste-water irrigation area, north-east of Paris, with indication of the position of the polluted (P1, P2) and the reference $(\mathrm{R})$ soils $(-)$ with respect to the position of irrigation water outlets $(\otimes)$ in the irrigation field studied. N184 is a national highway.

lowed by clay translocation, resulting in the formation of an eluvial E over an illuvial Bt horizon. Near to the edge of the limestone plateaux, Calcaric Cambisols occur, due to truncation of the soil mantle.

At the end of the 19th century, the almost flat topography of the plateau, in combination with the sandy texture of the surface horizons, was considered favourable to the infiltration of thousands of $\mathrm{m}^{3} \mathrm{ha}^{-1}$ year ${ }^{-1}$ of urban waste water. With time, however, this water became more and more loaded with mineral and organic contaminants, including metal pollutants. Mean concentrations of metal elements in raw waste water were estimated at $0.4 \mathrm{mg} \mathrm{Zn} \mathrm{litre}{ }^{-1}, \quad 0.05 \mathrm{mg} \mathrm{Pb}$ litre $^{-1}$, $0.9 \mathrm{mg} \mathrm{Cu}$ litre $^{-1}$, and $0.005 \mathrm{mg} \mathrm{Cd} \mathrm{litre}^{-1}$, by Védry et al. (2001). These authors reported an average total metal input for 100 years in the soils of these waste-water irrigated areas of $8.1 \mathrm{~kg} \mathrm{ha}^{-1}$ for $\mathrm{Cd}$ and $1621 \mathrm{~kg} \mathrm{ha}^{-1}$ for $\mathrm{Zn}$. However, a great variability in metal concentrations within an irrigation field can be observed today (Bourennane et al., 2006).

\section{Selection of soil profiles and sampling strategy}

The selection of study sites was based on an exhaustive pedogeochemical soil survey of 470 samples taken in surface horizons samples of the Pierrelaye Bessancourt irrigation area (Baize et al., 2002; Dère et al., 2006, 2007; Lamy et al., 2006). The results highlighted a generally strong accumulation of organic C $(0.8-8 \%), \mathrm{P}(0.2-1.3 \%)$, secondary carbonates $(2-6 \%)$ and of metal pollutants (150-3500 mg Zn kg-1, 80-1300 mg Pb $\mathrm{kg}^{-1}, \quad 20-800 \mathrm{mg} \mathrm{Cu} \mathrm{kg}^{-1}$, and $1-40 \mathrm{mg} \mathrm{Cd} \mathrm{kg}^{-1}$ ) (Baize et al., 2002). For the present study, we selected two soils under intensive waste-water irrigation in one irrigated field (P1, P2), and one profile outside the irrigation perimeter $(\mathrm{R})$ representing the non-irrigated reference soil (Figures 1, 2). P1 and P2 were chosen for their large contents of organic carbon and metals in the plough layer and the clear accumulation of $\mathrm{Zn}$ in the Bt horizon, thus enhancing the detection of distinctive metal distribution patterns in thin section studies. Both soils 


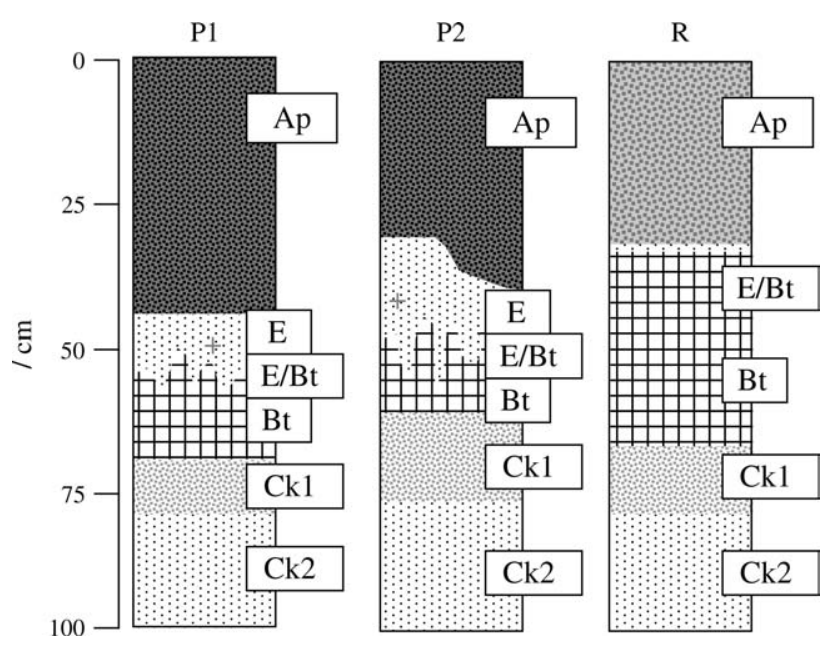

Figure 2 Schematic presentation of morphological development of the studied soils P1 (a), P2 (b), and R (c).

were under market garden management until the 1970s and since then have been under continuous maize cropping, whereas the $\mathrm{R}$ soil is still used today for food crop production.

The three study soils are developed under comparable pedoclimatological conditions, on the same limestone plateau, and with a comparable topographical location in well-drained positions, thus allowing a comparison of their morphological characteristics. Exhaustive physicochemical data of these soils were presented by Lamy et al. (2006) for the P1 and R soils (designated as PC01 and R-DBZ, respectively), and by Dère et al. (2006, 2007) for the P2 soil (designated as 'contaminated soil'). Some selected major chemical characteristics of the Ap horizons of the three soils, which emphasize the markedly larger concentrations of organic $\mathrm{C}$, and total $\mathrm{P}, \mathrm{CaCO}_{3}, \mathrm{Zn}, \mathrm{Pb}, \mathrm{Cu}$ and $\mathrm{Cd}$ in the two polluted soils in comparison with the reference soil, are presented in Table 1.

At each soil site, a large pit of about $1 \mathrm{~m} \times 1 \mathrm{~m}$ was excavated until the hard limestone (0.8-1-m depth). On three of the walls, macro-morphological characteristics of horizons and their genetic interpretation were studied. For the analyses, bulk samples of several kilograms were collected in all soil horizons distinguished in the field. Undisturbed samples for microscopical study were collected in cardboard boxes $(7 \mathrm{~cm} \times 7 \mathrm{~cm})$ in three

Table 1 Selected chemical data from the plough layer of the P1, P2 and $\mathrm{R}$ soils, analyses performed on quartered sub-samples of several $\mathrm{kg}$ of bulk samples from the Ap horizon

\begin{tabular}{|c|c|c|c|c|c|c|c|c|}
\hline \multirow[b]{2}{*}{ Soil } & \multirow[b]{2}{*}{$\mathrm{pH}$} & Org C & $\mathrm{P}$ & $\mathrm{CaCO}_{3}$ & $\mathrm{Zn}$ & $\mathrm{Pb}$ & $\mathrm{Cu}$ & $\mathrm{Cd}$ \\
\hline & & \multicolumn{3}{|c|}{$/ \mathrm{g} \mathrm{kg}^{-1}$} & \multicolumn{4}{|c|}{$/ \mathrm{mg} \mathrm{kg}^{-1}$} \\
\hline P1 & 7.4 & 41.8 & 6.7 & 40 & 1053 & 568 & 299 & 7.1 \\
\hline P2 & 7.3 & 30.4 & 5.7 & 28 & 982 & 436 & 259 & 4.7 \\
\hline $\mathrm{R}$ & 8.1 & 7.9 & 1.3 & 18.4 & 33 & 16.5 & 7.6 & 0.23 \\
\hline
\end{tabular}

replicates in the surface horizon, in and at the boundaries of deeper soil horizons, thereby assuring that all morphological features were representatively sampled.

\section{Methods}

Field characteristics and horizon designation were examined using FAO guidelines for soil description (FAO, 2006). Bulk samples were air-dried, ground and sieved to $2 \mathrm{~mm}$ and quartered sub-samples were stored for chemical analyses. Organic carbon contents (ISO 142-35, AFNOR, 1996) were determined following current international standardized methods. Total element concentrations were determined afterwards by tri-acid (HF, $\mathrm{HClO}_{4}$ and $\mathrm{HCl}$ : NF X31-151, AFNOR, 1996) digestion of sub-samples. Concentrations of $\mathrm{Ca}, \mathrm{Zn}$ and $\mathrm{Cu}$ were determined by inductively coupled plasma - atomic emission spectrometry (ICP-AES), and $\mathrm{Pb}$ and $\mathrm{Cd}$ by mass spectrometry (ICP-MS).

The undisturbed samples were impregnated under vacuum with polyester resin (synolith 544, Euroresins Benelux BV, Budel, the Netherlands), and after polymerisation, thin sections of 30- $\mu \mathrm{m}$ thickness were prepared according to the methods of FitzPatrick (1970). These were studied with a petrographic polarizing light microscope by means of plane and crossed polarized light and described according to the terminology of Stoops (2003). Additional $3 \mathrm{~cm} \times 4.5 \mathrm{~cm}$ uncovered thin sections were prepared on ultra-pure silica Suprasil ${ }^{\circledR}$ glass slides for spectroscopic study.

Synchrotron X-ray microfluorescence ( $\mu$-SXRF) was performed at LURE (Orsay, France) on small areas, ranging from $0.2 \mathrm{~mm}^{2}$ to $2 \mathrm{~mm}^{2}$ on thin sections to determine major ( $\mathrm{Si}, \mathrm{K}$, $\mathrm{Ca}, \mathrm{Ti}, \mathrm{Fe}$ and $\mathrm{Mn}$ ) and trace elements $(\mathrm{Cr}, \mathrm{Ni}, \mathrm{Zn}, \mathrm{Cu}$ and $\mathrm{Pb})$. These areas were selected after careful micromorphological study and considered to be representative of characteristic microfabrics and features observed in surface and subsurface horizons of the P1 and P2 soils. Altogether, more than 10 metal distribution maps were made with replicates on comparable microfabrics and features in the two soils showing great similarities in metal distribution patterns. Elemental maps were produced with a $20-\mu \mathrm{m}$ beam spot, excitation X-ray energy of $14 \mathrm{keV}$, at room temperature on the bending magnet beam line D15A. As measurements were performed in ambient atmospheric conditions, the detection of $\mathrm{Cd}$ was inhibited by the presence of argon (Chevallier et al., 1996). Spatial resolution was $25-\mu \mathrm{m}$ step size for $(\mathrm{x}, \mathrm{y})$. The advantage of this technique is its good detection limit $\left(\sim 1-10 \mathrm{mg} \mathrm{kg}^{-1}\right)$ for elements with atomic number $>20$ (Chevallier et al., 1996), which is favourable for studies of the distribution of heavy metals. This technique can be applied on uncovered thin sections as well as on separated particles (van Oort et al., 2006; Labanowski et al., 2007), providing semi-quantitative results, with metal concentration expressed in counts per step-size and acquisition time. Although well adapted for the detection of small metal contents in solid matter, the dwell-time for representative 
acquisition of a given trace metal element requires a compromise between reliable detection of the metal and the size of the analysed surface, with respect to a limited number of runs available each year. The obtained $\mu$-SXRF spectra were processed using VIRESYME software (Wang et al., 1993).

\section{Results}

\section{Macromorphology}

Selected macromorphological data of the soil profiles studied are presented in Table 2. A first, striking, aspect of the wastewater irrigated soils $\mathrm{P} 1$ and $\mathrm{P} 2$, was the prominent black colour (10 YR 3/1-3/2 under field moist conditions), observed in the plough layer, as well as their friable and sticky consistency, despite the sandy texture. Strong effervescence with ca $1 \mathrm{M}$ $\mathrm{HCl}$ pointed to the presence of $\mathrm{CaCO}_{3}$, ascribed to secondary carbonates formed by precipitation from evaporating waste water. The presence of some allochthonous fragments in the Ap horizons of these soils attested to occasional additions of household waste refuse, a current practice in market garden soils. The Ap horizons were frequently thicker than $40 \mathrm{~cm}$ (Figure 2), sometimes partly developed in the eluviation horizon as a result of deep ploughing. The abruptness of the transition from the Ap to the E horizon was a second striking aspect. The sandy textured, non-calcareous, bleached eluvial soil horizon had a brownish grey to dull yellow orange colour (10 YR 7/3) in the upper part, and was very friable. A third striking characteristic was observed in the lower part of this $\mathrm{E}$ horizon, where irregularly shaped, faint to distinct, coarse, bright orange-brown (7.5 YR 6/6 to 5/6 in P1) and dull reddish brown mottles (5 YR 5/6 in P2) occurred. Their number and size increased towards the Bt horizon. In the upper few $\mathrm{cm}$ of this Bt horizon, discrete grey/orange-brown iron mottling was also noted and the mottles in both horizons suggested the occurrence of pseudogley phenomena in the sandy E overlying a less permeable Bt horizon. As a result, the boundary between the eluvial and illuvial horizons was gradual and irregular to broken. The non-carbonated Bt horizon is of clayey sandy texture and a brown to reddish brown (7.5 YR 4/6-4 YR 5/6) colour, with a firm and sticky consistency. The $\mathrm{C} 1$ horizon displayed strong effervescence. Alternating zones with pale grey-yellow colours (2.5 YR 8/4) were observed and corresponded to carbonate-rich areas; more brownish colours (10 YR 6/5) were ascribed to the weathering of carbonates and the liberation of clay and iron compounds. In the Ck2 horizon $(>80 \mathrm{~cm})$, the amount of pale brown to pale yellow hard carbonate rock fragments increased.

The Ap horizon of the R soil was bright brown (10 YR 4/4). Effervescence was less strong, and the consistency was friable to loose. The Ap was about $30 \mathrm{~cm}$ thick (Figure 2) and contained some allochthonous fragments ascribed to various additions related to market garden land use. No mottling was observed in the $\mathrm{E} / \mathrm{Bt}$ transition and horizon boundaries were smooth.

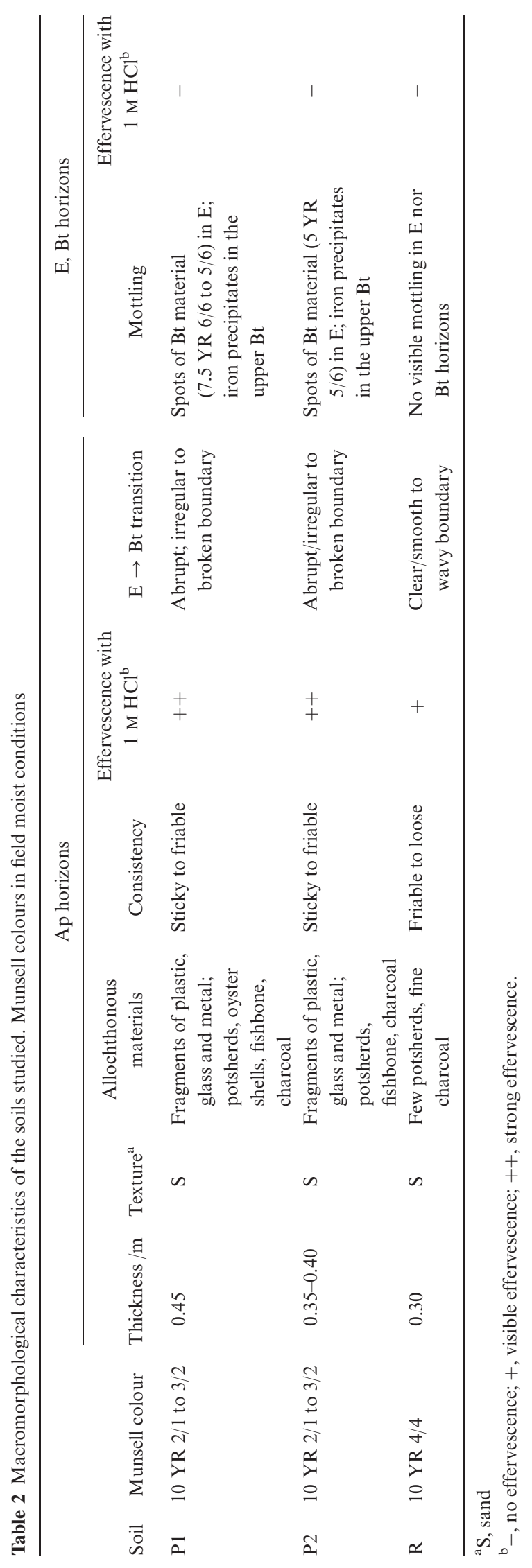




\section{Micromorphology}

The Ap horizon. Optical microscopy images from the thin sections of the plough layers were consistent with the sandy character of the three soils studied, with a dominant quartz skeleton grain composition (Figure 3a-e). In addition, coarse- and finesized particles of anthropogenic origin such as charcoal, fishbones, industrial slag or plastic fragments were observed for the three study soils (Figure 3e).

In the R soil, the fine groundmass $(<20 \mu \mathrm{m})$ was composed dominantly of finely-divided, reddish-brown organic matter, occurring as thin pseudo-coatings around coarse mineral grains in a dominant chitonic-related distribution pattern (Figure 3a). Yellowish-orange clay-iron compounds and few to common (5$15 \%$ ), fine and coarse carbonate crystals with characteristic high interference colours were present (Figure 3d). As the underlying $\mathrm{E}$ and $\mathrm{Bt}$ horizons were non-calcareous, the presence of carbonate crystals in the surface horizon suggested an anthropogenic origin, due to periodic liming.

By contrast, in the Ap horizons of the P1 and P2 soils the amount of fine groundmass was greater than in the R soil and occurred as small aggregates in a dominant enaulic-related distribution pattern (Figure 3b,c), often completely filling simple packing voids between coarse sand grains. The aggregates consisted mainly of very dark coloured, finely divided organic components with no visible cell structure, masking the occurrence of fine clay and iron compounds. The organic matter was intimately mixed with abundant $(40-80 \%)$, very fine $(5-10 \mu \mathrm{m})$ crystals of carbonate (Figure 3e), related to precipitation of salts from evaporating irrigation water at the soil's surface. In addition, yellowish-green crystals, optically interpreted as iron phosphates (cf. Figure 5a), and many opaque black, often coarse silt-sized charcoal particles (Figures 3e, 4a), were frequently observed, corroborating a strong anthropogenic influence in these waste-water irrigated surface horizons.

Subsurface horizons. In the upper parts of the E horizons of P1 and $\mathrm{P} 2$, directly underlying the sharply bounded Ap horizon, fine groundmass material was occasionally observed, both in intergranular packing voids and on the surface of skeleton grains. At the transition towards the Bt horizon, few thin greyyellow, grainy, non-translucent clay coatings occurred, exhibiting low birefringence (Figure 3f,g). In the Bt horizons, pure yellow-orange, translucent clay-iron coatings were observed with strong birefringence, occasionally filling up simple packing voids (Figure 3i,j). This occurrence in the Bt was consistent with the clay illuviation character of the Luvisols. The coatings were more strongly developed in the Bt of P1 than in that of P2. Locally, thin $(10-30 \mu \mathrm{m})$ opaque iron-manganese coatings covering the clay coatings were observed in the upper parts of Bt horizons in P1 and P2 (Figure 3i,j), suggesting pseudogley processes.

By contrast, in the $\mathrm{E} / \mathrm{Bt}$ and $\mathrm{Bt}$ horizons of the $\mathrm{R}$ soil (Figure $3 \mathrm{~h}, \mathrm{k})$, yellowish-orange, translucent clay coatings with a strong birefringence occurred. These coatings were similar to the translucent clay coatings observed in the two polluted soils. However, grainy, non-translucent clay coatings and neo-formed ironmanganese coatings were absent in the $\mathrm{E} / \mathrm{Bt}$ and $\mathrm{Bt}$ horizons (Figure 3k), signifying that pseudogleying has not affected the non-irrigated reference soil.

Thin sections of the $\mathrm{Ck}$ horizons of the three soils (not shown here) showed various stages of dissolution of the limestone, and the occurrence of large and fine, needle-shaped secondary carbonate crystals, and mycelium. Coarse sand skeleton grains, mainly quartz, feldspars and green-yellow glauconite were liberated, as well as a reddish-brown, fine-textured groundmass composed of clay and iron oxide, forming the basic mineral components for soil formation.

\section{Microscale chemical distribution patterns in the P1 and P2 soils}

In the selected elemental distribution maps obtained by $\mu$ SXRF, presented in Figures 4, 5, 7 and 8, the maximal detected counts/run-time were lowered to arbitrarily chosen maximum values ( $m a x ')$, in order to optimize the contrast between distribution patterns. As a result, both diffusely distributed metal elements with moderate concentrations and local hot spots of large concentrations could be assessed in the same map.

Diffuse metal distribution in the Ap horizons. We performed $\mu$-SXRF on a $525 \mu \mathrm{m} \times 1250 \mu \mathrm{m}$ area of the groundmass of the Ap horizon of P1 (Figure 4a). The selected surface included the characteristic enaulic-related microstructure of organic groundmass aggregates around coarse-sized skeleton grains (cf. Figure $3 \mathrm{~b}, \mathrm{c}, \mathrm{e})$. A large fragment of particulate organic matter (POM) occurred in the centre of the section studied as well as a small iron oxide compound (Fe-ox) in the bottom part. Distribution maps of Si and K (Figure 4b) coincided with distinct locations corresponding to grains of quartz (Q) and K-feldspar (F). Calcium was present both in POM and in organic groundmass aggregates. These observed contrasting distributions were confirmed by the absence of $\mathrm{K}$ to $\mathrm{Si}$ and $\mathrm{K}$ to $\mathrm{Ca}$ correlations (Table 3, panel a), and a negative $\mathrm{Ca}$ to $\mathrm{Si}$ correlation. Iron was dominantly observed in POM and in the iron oxide compound. In addition, notable Fe concentrations were also present in the fine groundmass, forming a network around coarse skeleton grains.

Distribution maps of $\mathrm{Zn}$ and $\mathrm{Fe}$ showed great similarities, confirmed by strong $\mathrm{Zn}$ to Fe correlation $(r=0.94$, Table 3, panel a). Lead was also detected in POM and in the organic groundmass coatings, but it was particularly concentrated in the iron oxide particle, as confirmed by a strong and increased correlation coefficient of $\mathrm{Pb} / \mathrm{Fe}$ when restricting the area of mathematical analysis from the map to the iron compound (Table 3, panel a). Copper occurred predominantly in POM and appeared less strongly associated with iron oxide than $\mathrm{Pb}$, as confirmed by a decreasing $r_{\mathrm{Cu} / \mathrm{Fe}}$ coefficient when focussing on the iron oxide particle. 

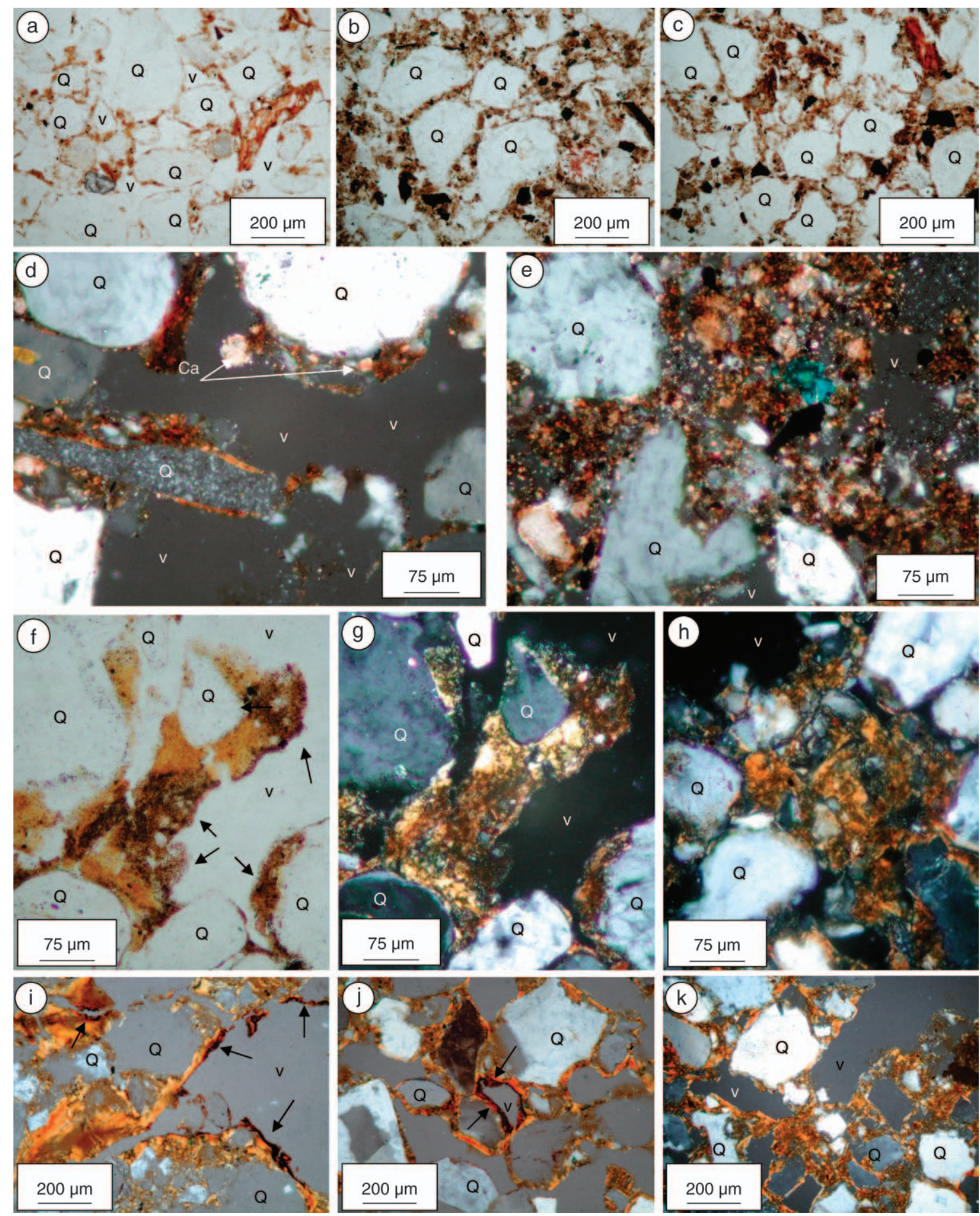

Figure 3 Optical microscopy images of characteristic soil constituents, microstructures and features studied in soil thin sections of selected horizons of the waste-water irrigated (P1, P2) and reference (R) soils. Detailed descriptions are in the text. (a) Ap horizon of the R soil (PPL, $\times 100)$; (b, c) Ap horizons of, respectively, the P1 and P2 soils (PPL, $\times 100$ ); (d) detail view of microstructure in the R-Ap horizon, white arrows indicate calcium-carbonate crystals (XPL, $\times 200$ ); (e) detail view of the urban organic matter groundmass in the Ap horizons of the waste water irrigated soils, the blue spot corresponds to a small plastic fragment (XPL, × 200); (f, g) E/Bt horizon of P1 and P2 soils (f: PPL, g: XPL, × 200); (h) E/Bt horizon of the R soil (XPL, $\times 200$ ); (i, j) Bt horizons of P1 and P2 soils, respectively, showing iron-manganese coatings (black arrows) covering yellowish-orange, translucent clay coatings (XPL, $\times 200)$; $(\mathrm{k})$ Bt horizon of the R soil (XPL, $\times 200)$. Q, quartz; Ca, carbonate; v, voids; PPL, plain polarized light; XPL, crossed polarized light. 

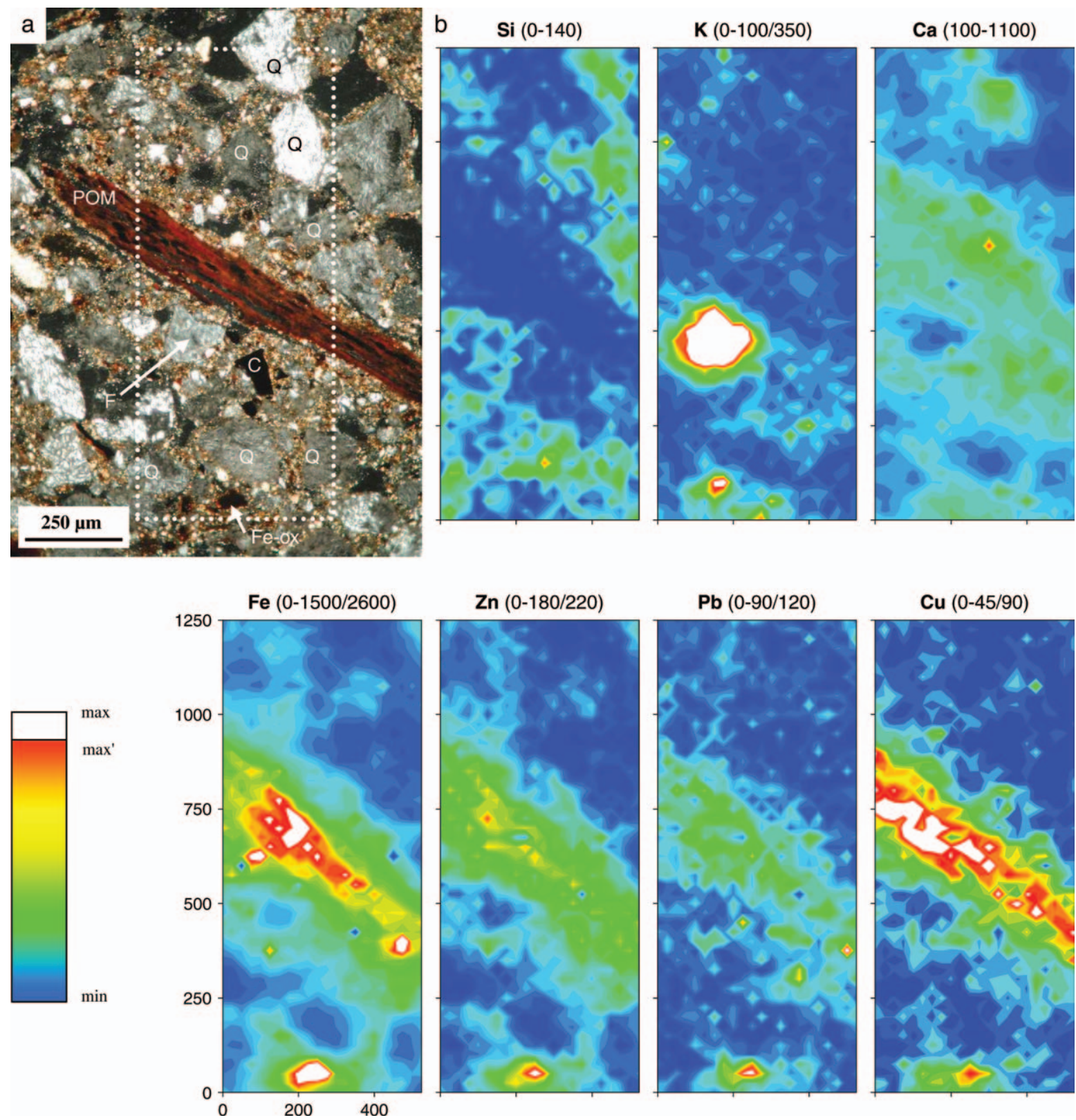

Figure 4 Optical microscopy image in crossed polarized light of the characteristic soil groundmass in the Ap horizon of the P1 soil (a) and related elemental distribution maps obtained by $\mu$-SXRF (b). Q, quartz; F, feldspar; C, charcoal; POM, particulate organic matter, Fe-ox., iron oxide particle; analysed surface, $\mathrm{x}=525 \mu \mathrm{m}, \mathrm{y}=1250 \mu \mathrm{m}$, acquisition time $\mathrm{t}=60 \mathrm{~s} / 25 \mu \mathrm{m}^{2}$.

Local concentrated metal distributions in the Ap horizons. In Figure $5 \mathrm{a}$, the $575 \mu \mathrm{m} \times 375 \mu \mathrm{m}$ area analysed included an 80 $\mu \mathrm{m}$, yellowish-green, and a $60-\mu \mathrm{m}$, reddish-brown spherical mineral phase. They were identified optically as iron and calcium phosphate grains, respectively (noted 'P' in Figure 5a). Maps of the major elements $\mathrm{Si}, \mathrm{K}, \mathrm{Ca}$ and $\mathrm{P}$ showed distinct distributions (Figure 5b) related to the occurrence of large quartz grains, K-feldspar and the $\mathrm{Ca}$ phosphate particle, as confirmed by the absence of, or negative correlation between, these elements (Table 3, panel b). Iron was strongly concen- trated in the iron phosphate grain and in a small Fe-oxide particle (Fe-ox), visible in the centre of Figure 5a. Calcium and iron were also detected in the fine organic groundmass, but with markedly smaller concentrations than in the phosphate and iron oxide particles. Manganese was present in the $\mathrm{Fe}$ phosphate particle, and occurred more diffusely around the Ca phosphate particle.

The elements $\mathrm{Zn}, \mathrm{Pb}$ and $\mathrm{Cu}$ showed rather similar distribution patterns, with large concentrations in phosphate grains, particularly in the Ca phosphate. This simultaneous presence 

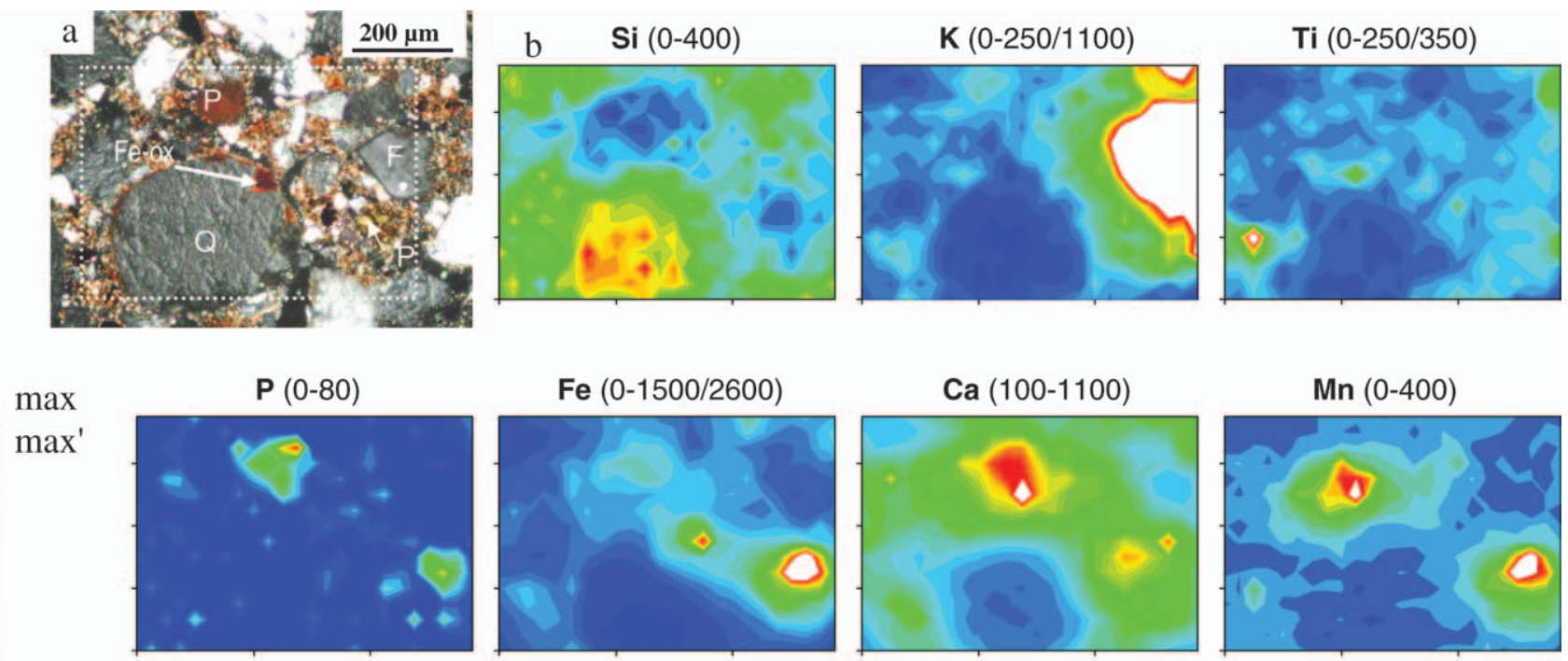

$\min$
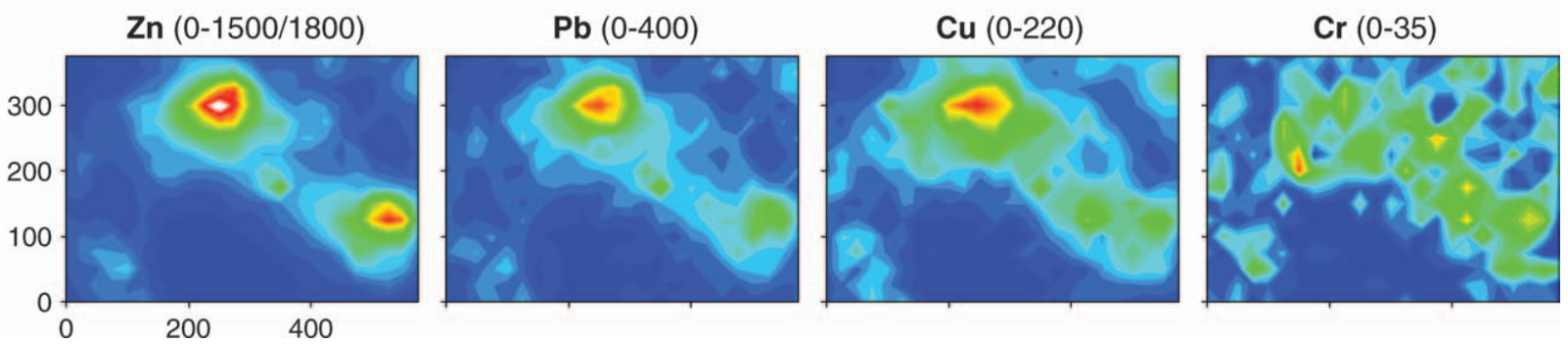

Figure 5 Optical microscopy view in crossed polarized light of phosphate particles in the Ap horizon of the P2 soil (a) and related chemical distribution maps obtained by $\mu$-SXRF (b). Q,: quartz; F, feldspar; P, phosphate minerals; Fe-ox., iron oxide particle; analysed surface, $\mathrm{x}=575 \mu \mathrm{m}$, $\mathrm{y}=375 \mu \mathrm{m}$, acquisition time $\mathrm{t}=170 \mathrm{~s} / 25 \mu \mathrm{m}^{2}$.

was underlined by strong correlations between $\mathrm{Zn}$ and $\mathrm{Cu}, \mathrm{Pb}$ and $\mathrm{Cu}$, as well as $\mathrm{Zn}$ and $\mathrm{Pb}$ (Table 3, panel b). However, correlation coefficients between the metals and $\mathrm{P}$ were small $(0.5<r<0.7)$, due to the additional diffuse distribution of $\mathrm{Zn}, \mathrm{Pb}$ and $\mathrm{Cu}$ in the fine organic groundmass. At the scale of the $575 \mu \mathrm{m} \times 375 \mu \mathrm{m}$ section studied, the correlation between trace metals and $\mathrm{Fe}$ was also poor $(0.5<r<0.7)$, as between metals and Mn (not shown). Detailed examination of the correlation diagrams for $\mathrm{Zn}, \mathrm{Pb}$ and $\mathrm{Cu}$ with $\mathrm{Fe}$ (Figure 6) reveals two lines of data points, illustrating the association of trace metals with iron in different soil phases: in Ca phosphate (1), in Fe phosphate or Fe oxide (2), or diffuse presence in the organic matrix coatings (3). The same trends were observed for correlations of trace metals with $\mathrm{Ca}$, and with $\mathrm{Mn}$.

Metal distributions at the boundary of the Ap horizon. Elemental mapping was used to evaluate how distinctly the microscale distribution of metal pollutants responded to an in-field noted abrupt horizon boundary. To this end, we performed $\mu$ SXRF over a $575 \mu \mathrm{m} \times 3000 \mu \mathrm{m}$ area, focussing on the Ap $\rightarrow \mathrm{E}$ horizon transition (Figure 7a). General distribution of Si (Figure $7 b$ ) agreed well with the distribution of quartz grains. Silica was more abundant in the E horizon, corroborating the larger sand content. Potassium was detected predominantly in the groundmass of the Ap horizon, and occurred occasionally between quartz grains in the $\mathrm{E}$ horizon. The distribution of $\mathrm{Fe}$ showed clear concentrations just above the $\mathrm{Ap} / \mathrm{E}$ transition. In addition, Fe was largely present in the fine organic groundmass in the Ap horizon, and to a lesser extent around skeleton grains in the $\mathrm{E}$ horizon. The small iron-rich spot located at $(\mathrm{x}=50, \mathrm{y}=1225)$, just below the Ap/E limit, corresponded to a small amphibole particle. Distinct distribution patterns were observed for $\mathrm{Ca}$ in the Ap horizon, corresponding to a coarse carbonate grain, and to its presence as small secondary carbonate crystals in the fine organic groundmass. The lack of Ca detection from the very first $\mathrm{mm}$ in the $\mathrm{E}$ horizon was striking, consistent with the noted absence of effervescence in the E horizon as a whole.

Distribution patterns of trace metals were fairly well revealed in the Ap horizon, despite the short acquisition time (50 s/25$\mu \mathrm{m}^{2}$ beam step-size). They were observed mainly on the fine organic groundmass, but spots with large concentrations also occurred, associated with iron-rich components. The distribution patterns of $\mathrm{Zn}, \mathrm{Pb}$ and $\mathrm{Cu}$ showed strong similarities, confirmed by strong correlation coefficients (Table 3, panel c). Like $\mathrm{Ca}, \mathrm{Pb}$ was not detected in the $\mathrm{E}$ horizon, and the transition of $\mathrm{Pb}$ detection at the $\mathrm{Ap} / \mathrm{E}$ horizon limit was extremely 

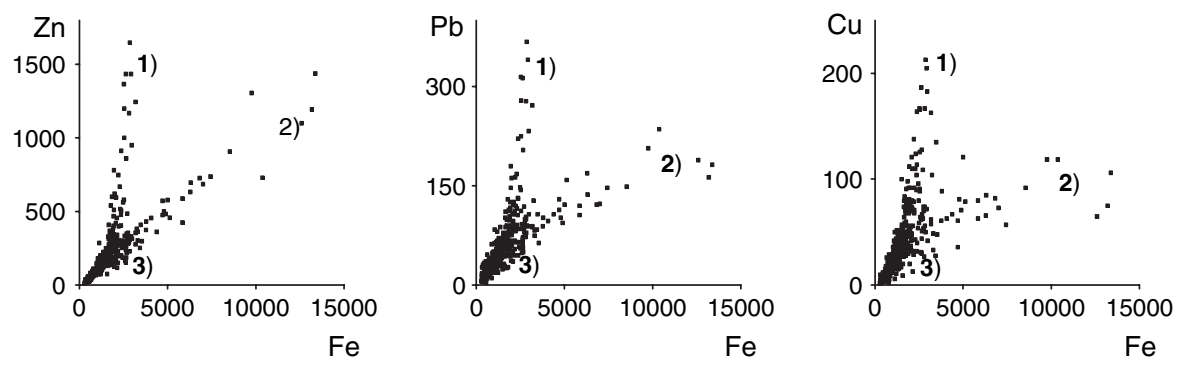

Figure 6 Selected graphs of $\mathrm{Zn}$ to $\mathrm{Fe}, \mathrm{Pb}$ to $\mathrm{Fe}$, and $\mathrm{Cu}$ to $\mathrm{Fe}$ correlation of the elemental maps presented in Figure 5, showing two trends of data points, with three segments corresponding to distinct metal associations with: the Ca phosphate particle (1), the Fe phosphate particle (2), and the organic groundmass pseudo-coatings (3); results expressed in counts/170 s for $575 \mu \mathrm{m} \times 375 \mu \mathrm{m}$.

abrupt. By contrast, $\mathrm{Zn}$ was detected in the E horizon, with a distribution pattern similar to those of $\mathrm{Fe}$ and $\mathrm{K}$, suggesting that $\mathrm{Zn}$ was sorbed by the small amounts of clay-iron groundmass occurring in the eluvial horizon. In this $\mathrm{E}$ horizon, $\mathrm{Cu}$ concentrations were detected occasionally, coinciding with small organic fragments, as was confirmed by micromorphology.
Major metal distribution patterns in the Bt horizons. In the clay-illuviated horizon, $\mu$-SXRF was performed on a $625 \mu \mathrm{m}$ $\times 450 \mu \mathrm{m}$ area, focussing on translucent clay-iron coatings around quartz grains, centred on a large biopore, with darkbrown, thin, oxide coatings at the surface (Figure 8a). A quartz grain with its clay-iron coating is visible in the centre of the
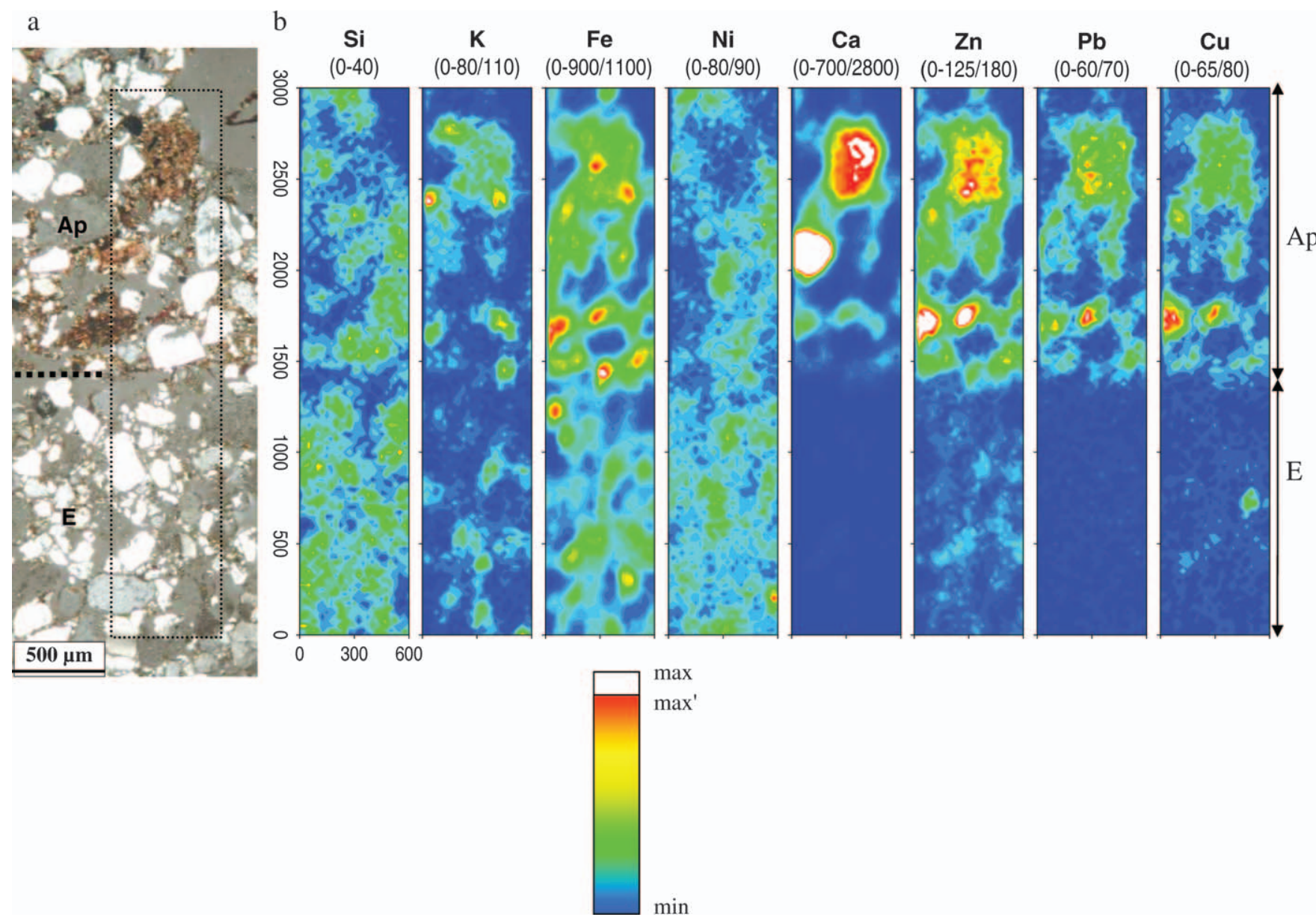

Figure 7 Optical microscopy view in crossed polarized light of the area studied of the boundary between the Ap and E horizons in the P1 soils (a) and related chemical distribution maps obtained by $\mu$-SXRF (b). Q, quartz; Ca, calcium carbonate mineral; analysed surface, $\mathrm{x}=600 \mu \mathrm{m}$, $\mathrm{y}=3000 \mu \mathrm{m}$, acquisition time $\mathrm{t}=50 \mathrm{~s} / 25 \mu \mathrm{m}^{2}$. 

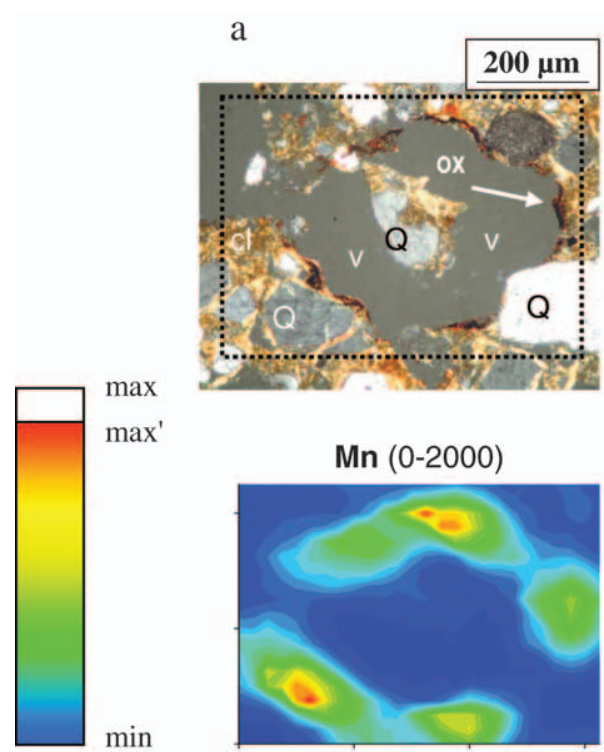

$b$
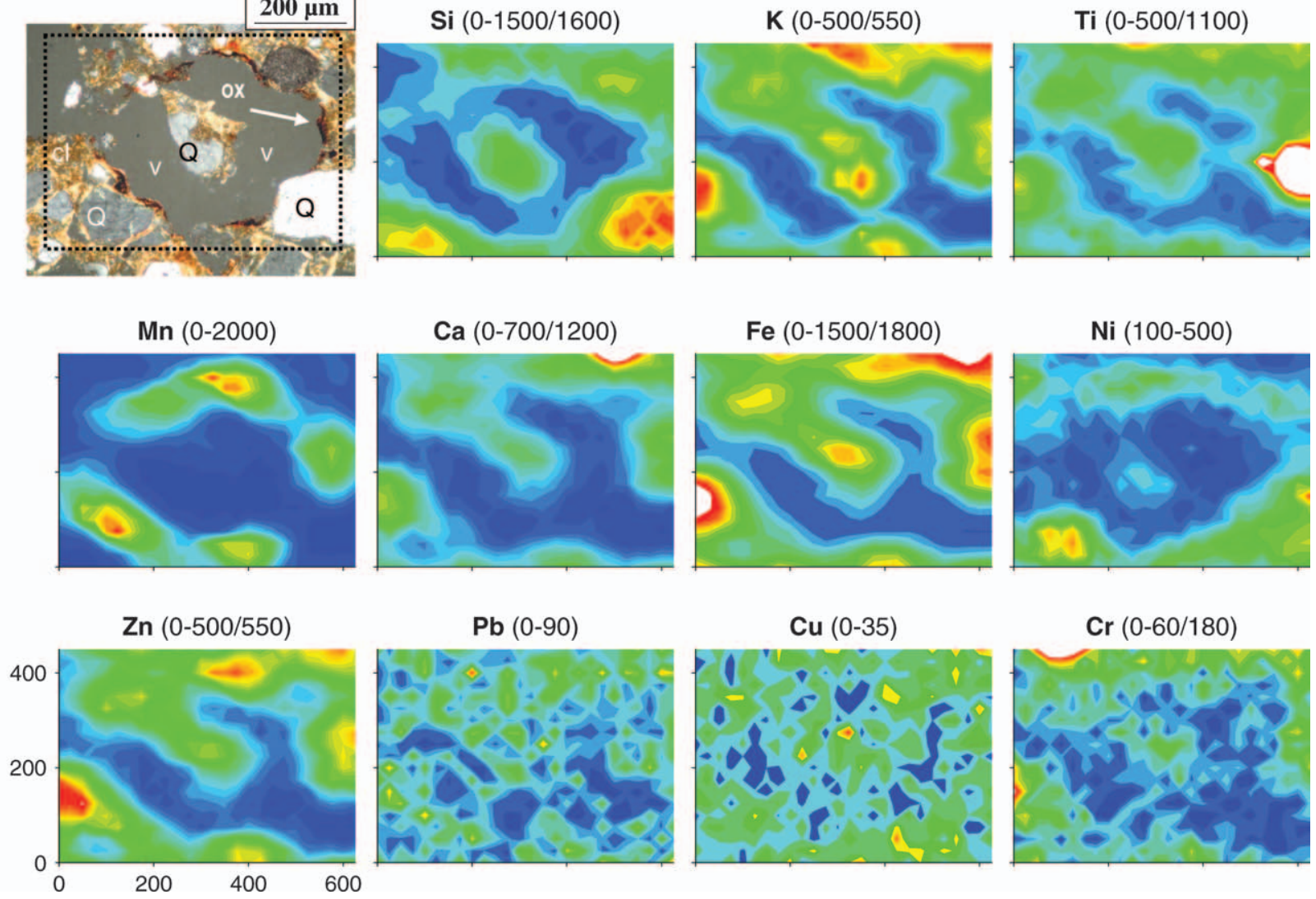

Figure 8 Optical microscopy view in crossed polarized light of yellowish-orange, translucent clay coatings on the inner surface of voids covered by thin neoformed iron-manganese coatings in the Bt horizon of the P2 soil (a) and related chemical distribution maps obtained by $\mu$-SXRF (b). $\mathrm{Q}$, quartz; v, void; cl, clay-iron coating; ox, oxide coating; analysed surface, $\mathrm{x}=625 \mu \mathrm{m}, \mathrm{y}=450 \mu \mathrm{m}$, acquisition time $\mathrm{t}=300 \mathrm{~s} / 25 \mu \mathrm{m}^{2}$.

biopore. The shape and location of the void and the large quartz grain at the lower right angle confer a particular element distribution patterns, visible in most maps of Figure 8b. The detection of $\mathrm{Si}$ was maximal in sand-sized quartz grains, but the distribution patterns related to smaller Si concentrations coincided with the network of clay coatings. Distribution maps of $\mathrm{Fe}, \mathrm{Ca}, \mathrm{K}$ and $\mathrm{Ti}$ showed strong similarities, consistent with a distribution pattern of smaller Si concentrations (except for the local occurrence of a Ti oxide grain). This related occurrence of $\mathrm{Si}, \mathrm{Fe}, \mathrm{K}, \mathrm{Ca}$ and $\mathrm{Ti}$ coincided with the clay-iron plasma, as confirmed by strong correlations between $\mathrm{Ca}$ and $\mathrm{Fe}, \mathrm{K}$ and $\mathrm{Fe}$, and $\mathrm{Ti}$ and $\mathrm{Fe}(r=0.63$, increasing to 0.92 when excluding data from the Ti oxide particle, cf. Table 3, panel d). The manganese distribution coincided with the location of thin iron-oxide coatings at the surface of the pore.

The distribution of $\mathrm{Zn}$ in the Bt horizon was strongly related to $\mathrm{Fe}$, and well related to $\mathrm{K}$ and $\mathrm{Ca}$ (Table 3, panel d). These results indicate that $\mathrm{Zn}$ accumulated predominantly in the clayiron coatings. No clear distribution patterns were observed for $\mathrm{Pb}$ and $\mathrm{Cu}$ in the $\mathrm{Bt}$ horizons of $\mathrm{P} 1$ and $\mathrm{P} 2$, suggesting little or no migration of these metal pollutants. Ni seemed to be preferen- tially associated with quartz grains, pointing to an endogenous origin. No correlation of $\mathrm{Ni}$ with $\mathrm{Fe}, \mathrm{Ca}, \mathrm{K}$ or Ti was observed, whereas $r_{(\mathrm{Ni} / \mathrm{Si})}$ rose to 0.69 . Chromium showed a strong localized concentration, ascribed to a spinel grain, and distribution patterns of smaller $\mathrm{Cr}$ concentrations coincided with clay-iron coatings. These results confirm the findings of Lamy et al. (2006) and Dère et al. (2006), who showed that $\mathrm{Ni}$ and $\mathrm{Cr}$ concentrations in deeper horizons of these waste-water irrigated soils were representative of the geochemical background.

\section{Discussion}

Characteristic associations of trace metals and soil constituents assessed with $\mu$-SXRF

Metal pollution in soils is often referred to as 'complex' and 'heterogeneous' due to the great variability of mineral and organic constituents, biological activity and human influences as underlined in several studies by electron-microscopic and (micro)-spectroscopic analysis (Jones \& Doner, 1998; Manceau et al., 2002; Jacobson et al., 2007). But by comparing $\mu$-SXRF 
Table 3 Correlation coefficients $(r)$ between major and metal elements in distribution maps obtained by $\mu$-SXRF (Figures 4, 5, 7, 8)

(a) Ap horizon: diffuse metal distribution (Figure 4); na, not appropriate

\begin{tabular}{|c|c|c|c|c|c|c|c|c|c|}
\hline \multirow[b]{2}{*}{ Correlation } & \multicolumn{3}{|c|}{ Metals/Fe } & \multicolumn{2}{|c|}{ Metals/Major } & \multicolumn{4}{|c|}{ Major } \\
\hline & $\mathrm{Zn} / \mathrm{Fe}$ & $\mathrm{Cu} / \mathrm{Fe}$ & $\mathrm{Pb} / \mathrm{Fe}$ & $\mathrm{Zn} / \mathrm{Ca}$ & $\mathrm{Zn} / \mathrm{Si}$ & $\mathrm{Ca} / \mathrm{Fe}$ & $\mathrm{K} / \mathrm{Ca}$ & $\mathrm{K} / \mathrm{Si}$ & $\mathrm{Ca} / \mathrm{Si}$ \\
\hline$r_{\text {map }}(n=1122)$ & 0.94 & 0.85 & 0.77 & 0.63 & -0.51 & 0.59 & -0.01 & -0.01 & -0.52 \\
\hline$r_{\text {iron oxide }}(n=47)$ & 0.97 & 0.77 & 0.92 & na & na & na & na & na & na \\
\hline
\end{tabular}

(b) Ap horizon: localised metal distribution (Figure 5)

\begin{tabular}{|c|c|c|c|c|c|c|c|c|c|c|c|}
\hline Correlation & $\frac{\text { Major }}{\mathrm{Si} / \mathrm{Ca}}$ & \multicolumn{4}{|c|}{ Metals/P } & \multicolumn{3}{|c|}{ Metals/Fe } & \multicolumn{3}{|c|}{ Metals } \\
\hline$r_{\text {map }}(n=384)$ & -0.73 & 0.47 & 0.70 & 0.62 & 0.47 & $0.71^{\mathrm{a}}$ & $0.60^{\mathrm{a}}$ & $0.52^{\mathrm{a}}$ & 0.95 & 0.88 & 0.91 \\
\hline
\end{tabular}

(c) Ap/E transition (Figure 7)

\begin{tabular}{lcccccc}
\hline & \multicolumn{3}{c}{ Metals } & \multicolumn{2}{c}{ Metals/Major } \\
\cline { 2 - 4 } Correlation & $\mathrm{Zn} / \mathrm{Pb}$ & $\mathrm{Zn} / \mathrm{Cu}$ & $\mathrm{Cu} / \mathrm{Pb}$ & $\mathrm{Zn} / \mathrm{Fe}$ & $\mathrm{Pb} / \mathrm{Fe}$ & $\mathrm{Zn} / \mathrm{Ca}$ \\
$r_{\text {map }}(n=384)$ & 0.90 & 0.88 & 0.80 & 0.80 & 0.70 & 0.51 \\
\hline
\end{tabular}

(d) Bt horizon: dominant metal distribution (Figure 8)

\begin{tabular}{|c|c|c|c|c|c|c|c|c|c|c|c|c|c|c|}
\hline \multirow{3}{*}{$\begin{array}{l}\text { Correlation } \\
r_{\text {map }}(n=494)\end{array}$} & \multicolumn{4}{|c|}{ Major } & \multicolumn{8}{|c|}{ Metals/Major } & \multicolumn{2}{|c|}{ Metals } \\
\hline & $\mathrm{Ca} / \mathrm{Fe}$ & $\mathrm{K} / \mathrm{Fe}$ & $\mathrm{Ti} / \mathrm{Fe}$ & $\mathrm{Mn} / \mathrm{Fe}$ & $\mathrm{Zn} / \mathrm{Fe}$ & $\mathrm{Zn} / \mathrm{K}$ & $\mathrm{Zn} / \mathrm{Ca}$ & $\mathrm{Zn} / \mathrm{Ti}$ & $\mathrm{Zn} / \mathrm{Mn}$ & $\mathrm{Pb} / \mathrm{Fe}$ & $\mathrm{Pb} / \mathrm{Mn}$ & $\mathrm{Cu} / \mathrm{Fe}$ & $\mathrm{Zn} / \mathrm{Pb}$ & $\mathrm{Zn} / \mathrm{Cu}$ \\
\hline & 0.91 & 0.88 & $0.63^{\mathrm{a}}$ & 0.27 & 0.93 & 0.85 & 0.84 & 0.56 & 0.56 & 0.36 & 0.20 & 0.27 & 0.37 & 0.27 \\
\hline
\end{tabular}

${ }^{\mathrm{a}} \mathrm{Ti} / \mathrm{Fe}$ rose to 0.92 after removal of data from Ti oxide grains.

elemental mappings with micromorphological studies, such heterogeneity of metal distribution appeared fairly clear and coincides with specific soil constituents, microstructures and pedofeatures (Leguédois et al., 2004; van Oort et al., 2006, 2007; Jacobson et al., 2007). The limitation of such a combined approach is the pixel-size resolution of the beam spot used, which is several orders of magnitude larger than the nanometre-sized soil colloids, known for their high reactivity with metal elements (Kretzschmar et al., 1999). Therefore, metal distributions related to colloidal clays, iron oxides and/or humic substances may be assessed by $\mu$-SXRF when these colloids occur in characteristic pedofeatures, such as distinct clay or iron coatings (van Oort et al., 2006).

In the Ap horizons of the waste-water irrigated soils studied, two levels of metal concentrations were revealed with distribution patterns related to specific soil constituents and microstructures. A first level of locally occurring hot spots of large metal concentrations coincided with specific soil constituents such as phosphates, iron oxides and particulate organic matter (POM) fragments. The great reactivity of these constituents to metal pollutants is widely documented (Cotter-Howells, 1996; Fendorf et al., 2004; Labanowski et al., 2007), but such associations were not often illustrated clearly in situ. The second level of more moderate metal concentrations was rather diffusely distributed in the fine groundmass composed of finely divided organic aggregates mixed with secondary carbonate crystals, present around the coarse skeleton grains (cf. Figures
$4,7)$. Considering the ubiquity of occurrence of this enaulicrelated microstructure, this second level of metal concentrations definitely represents the predominant metal association in the surface horizons of the waste-water irrigated soils.

The $\mu$-SXRF metal distribution maps performed on the Ap - E horizon boundary, (Figure 7), revealed strongly contrasting geochemical associations, which are related to the occurrence or to the absence of organic groundmass. These findings imply that chemical conditions differ totally over a distance of less than a tenth of a $\mu \mathrm{m}$. This illustrates remarkably well how rapidly physicochemical conditions can vary in soils, and consequently, the importance, when dealing with environmental pollution problems, of using sampling strategies based on pedological horizons instead of arbitrarily selected soil depths. In our polluted soils, the simultaneous input of organic matter and dissolved compounds is likely to have acted as a sink in terms of metal immobilization in the surface horizon and prevented their migration to depth, particularly in the case of $\mathrm{Pb}$.

Copper was detected sporadically in the E horizon and coincided with the presence of small organic matter fragments. This $\mathrm{Cu}$ association corroborated its great affinity for organic matter (Jacobson et al., 2007; Sebastia et al., 2007, 2008). Zinc was also detected by $\mu$-SXRF in small concentrations below the Ap horizon boundary, associated with the small amounts of fine groundmass occurring in the eluvial horizon. But clear $\mathrm{Zn}$ accumulation was demonstrated in the Bt horizon with distribution patterns coinciding with the occurrence of pure, 
yellow-orange translucent clay-iron coatings. The great affinity of $\mathrm{Zn}$ to phyllosilicates and iron compounds in weakly and strongly metal-polluted soils has been mentioned frequently (Baize, 1997; Manceau et al., 2000) and illustrated by $\mu$-SXRF mapping on clay-rich B horizons (Leguédois et al., 2004; van Oort et al., 2006). These $\mathrm{Zn}$ accumulations were in agreement with the data from Lamy et al. (2006) and Dère et al. (2006, 2007) for $\mathrm{Zn}$ concentrations in the Bt horizons of the $\mathrm{P} 1$ (322 $\mathrm{mg} \mathrm{kg}^{-1}$ ) and the P2 (420 $\mathrm{mg} \mathrm{kg}^{-1}$ ) soils, compared with about $36 \mathrm{mg} \mathrm{kg}^{-1}$ measured in the $\mathrm{Bt}$ horizon of the $\mathrm{R}$ soil. However, as opposed to other findings (Manceau et al., 2000; Bataillard et al., 2003; van Oort et al., 2006), no accumulation of $\mathrm{Pb}$ was observed for the $\mathrm{Mn}$-rich iron oxihydroxides $\left(r_{(\mathrm{Pb} / \mathrm{Mn})}=0.2\right.$, Table 3, panel $\left.\mathrm{d}\right)$, suggesting the absence of $\mathrm{Pb}$ mobility in colloidal form, as shown recently in other metal-contaminated soils (Citeau et al., 2003; van Oort et al., 2006).

\section{Land use and soil development}

In addition to great changes in morphology observed in the surface horizons of the waste-water irrigated soils, impacts of long-term irrigation practices were also noted on soil features in deeper soil horizons. Macro- and micro-morphology showed that in the irregularly shaped and diffuse mottling zone forming the transition between the $\mathrm{E}$ and the Bt horizon, tiny greyyellow, grainy non-translucent clay coatings occurred in the continuity of pure yellow-orange, translucent clay coatings. These observations strongly suggested that pseudogleying was active and resulted in a ferrolysis-like process, which affected the lower parts of the E horizon at the expense of the Bt horizon. Ferrolysis is a hydromorphic, soil-forming process (Brinkman, 1979), based on biochemical reduction of iron oxides and re-oxidation due to alternating reducing and oxidizing conditions in soils. The process is well known in many tropical regions, with contrasting dry and wet seasons, and was also suggested to be active in temperate regions as the explanation for strong texture contrasts occurring in hydromorphic soils (Brinkman et al., 1973). Recently, however, Van Ranst \& De Coninck (2005) challenged the role of ferrolysis in temperate soils by putting forward a hypothesis of clay translocation to explain differences in texture and clay mineralogy. In our study soils, intensively irrigated over 100 years to give an accumulated water load of more than $2000 \mathrm{~mm}$ year $^{-1}+600 \mathrm{~mm}$ annual rainfall, the clay-iron rich $\mathrm{Bt}$ horizons were intermittently water-logged and dried as a result of weekly or monthly flooding. Under such conditions, ferrolysis is likely to be active. The presence of neo-formed iron-manganese coatings, observed in the upper Bt horizons of the P1 and P2 soils, and ascribed to precipitation of solubilized $\mathrm{Fe}$ and $\mathrm{Mn}$ cations from destruction of clay minerals in the $\mathrm{E} / \mathrm{Bt}$ horizon, was consistent with such a hydromorphic soil forming process. Iron-manganese coatings covered translucent clay coatings, indicating that clay illuviation and pseudogleying occurred not simultaneously but sequentially and that pseudogley processes developed after clay illuviation. Such impacts (i.e. the occurrence of grainy, non-translucent clay coatings in the $\mathrm{E} / \mathrm{Bt}$, and neo-formed iron-manganese coatings in the $\mathrm{Bt}$ horizons) were not observed in the non-irrigated reference soil, which demonstrated that pseudogleying and ferrolysis were closely related to waste-water irrigation.

\section{Consequences for metal migration}

In terms of metal distribution patterns, the origin of the precipitated $\mathrm{Fe}$ (and $\mathrm{Mn}$ ) in neoformed coatings is likely to be related to clay decomposition in the $\mathrm{E} / \mathrm{Bt}$ horizon where metal concentrations are small. Consequently, the observed abovementioned absence of $\mathrm{Pb}$ in the neoformed iron-manganese coatings in the $\mathrm{Bt}$ horizon is consistent with an origin of iron related to ferrolysis in the overlying E/Bt horizon. Apparently, this ferrolysis process proceeds with increasing depth. It first affects the upper part of the Bt horizon by reducing the capacity of clay fabrics to intercept dissolved metal cations such as $\mathrm{Zn}^{2+}$ and $\mathrm{Cd}^{2+}$ from the percolating soil solution. As a result, ferrolysis is likely to reduce the efficiency of this natural filter for downwardly migrating metal pollutants, and to increase risks with respect to their transfer through the bedrock and contamination of the groundwater. When clay destruction due to ferrolysis finally affects the entire Bt horizon, migrating dissolved metal pollutants will no longer be intercepted. Such an evolution of the soil properties of these sandy Luvisols is, among others, a possible explanation for the reported presence or absence of metal accumulation in the clayey B horizons of soils of the waste-water irrigated area (Lamy et al., 2006).

\section{Conclusions}

Two Luvisols irrigated for 100 years with urban waste water displayed strong metal accumulations and macro- and micromorphological features that were not observed in a non-irrigated reference soil. Our study showed that in the surface horizons of the waste-water irrigated soils, heterogeneous distribution patterns of metal pollutants occurred. At a micrometre scale, $\mu-$ SXRF mappings revealed fairly well organised or distinct distributions. Large metal concentrations were detected locally, coinciding with the occurrence of specific reactive constituents: phosphates, iron oxides, and particulate organic matter fragments. Yet, the predominant association of metal pollutants in these soils was undoubtedly related to more moderate metal concentrations detected on the omnipresent organic groundmass coatings around skeleton grains.

At the scale of soil horizons, metal retention and speciation was governed by the typical soil constituents and the local geochemical conditions, which may change greatly immediately after a horizon boundary. Our results demonstrate clearly why sampling strategies for assessing environmental risk related to 
the incorporation and leaching dynamics of metal pollutants in soils need to be based on soil horizons instead of arbitrarily selected soil depths. Finally, our work revealed a double filtering function of the sandy Luvisols for metal pollutants. First, a manmade filtering capacity has developed in the Ap horizon, due to the long-term input via the waste water of organic matter, with carbonates and phosphates largely immobilizing the simultaneously added metal pollutants. Second, the clay fabrics in the Bt horizons act as a natural filter, particularly for $\mathrm{Zn}$, by intercepting dissolved metals in the percolating soil solution. However, our study showed clay destruction due to ferrolysis initiated by excessively large irrigation rates and related alternating oxidation and reduction processes. Active ferrolysis processes would imply a reduction of the filtering capacity of the $\mathrm{Bt}$ horizon, and an increased risk of metal leaching towards the groundwater.

\section{Acknowledgements}

The authors thank Mr T. Lagadec, H. Pouillot and S. Breuil (INRA) for their help during the broad field sampling campaign, and sample preparation; and $\mathrm{Mr} \mathrm{A}$. van Dijk (WUR) for impregnation of soil samples and thin section production. Financial support of different national and regional institutions (CRIF, ADEME, DRIAF, DIREN and AESN) for the 'Epandagri' research fund is gratefully acknowledged.

\section{References}

AFNOR 1996. Qualité des sols. Recueil de normes françaises. AFNOR, Paris.

Baize, D. 1997. Teneurs totales en éléments traces métalliques dans les sols (France). INRA-Éditions, Versailles, France.

Baize, D., Lamy, I., van Oort, F., Dère, C., Chaussod, R., SappinDidier, V. et al. 2002. 100 years spreading of urban waste water on market-garden soils close to Paris (France): subsequent impacts and hazards. CDRom Transactions $17^{\text {th }}$ World Congress of Soil Science, CDRom paper 204. Bangkok, Thailand.

Bataillard, P., Cambier, P. \& Picot, C. 2003. Short-term transformations of lead and cadmium compounds in soil after contamination. European Journal of Soil Science, 54, 365-376.

Bourennane, H., Dère, C., Lamy, I., Cornu, S., Baize, D., van Oort, F. et al. 2006. Enhancing spatial estimates of metal pollutants in raw wastewater irrigated fields using a topsoil organic carbon map predicted from aerial photography. Science of the Total Environment, 361, 229-248.

Brinkman, R. 1979. Ferrolysis, a soil-forming process in hydromorphic conditions. Doctoral thesis, Wageningen Publications No 699, Wageningen, the Netherlands.

Brinkman, R., Jongmans, A.G., Miedema, R. \& Maaskant, P. 1973. Clay decomposition in seasonally wet, acid soils: micro-morphological, chemical, and mineralogical evidence from individual argillans. Geoderma, 10, 259-270.
Cebula, J. 1980. Contents of some trace elements in soils irrigated with municipal waste water. Environmental Protection Engineering, 6, 146-151.

Citeau, L., Lamy, I., van Oort, F. \& Elsass, F. 2003. Colloidal facilitated transfer of metals in soils under different land use. Colloids and Surfaces A, 217, 11-19.

Chevallier, P., Dhez, P., Legrand, F., Erko, A., Aganov, Y., Panchenko, L.A. et al. 1996. The LURE-IMT X-ray fluorescence photon microprobe. Journal of Trace and Microprobe Techniques, 14, 517-539.

Cotter-Howells, J.D. 1996. Lead phosphate formation in soils. Environmental Pollution, 93, 9-16.

Dère, C., Lamy, I., van Oort, F., Baize, D. \& Cornu, S. 2006. Reconstitution des apports en éléments trace métalliques et bilan de leur migration dans un Luvisol sableux soumis à 100 ans d'irrigation massive par des eaux usées brutes. Comptes Rendus Géoscience, 338, 565-573.

Dère, C., Lamy, I., Jaulin, A. \& Cornu, S. 2007. Long-term fate of exogenous metals in a sandy Luvisol subjected to intensive irrigation with raw wastewater. Environmental Pollution, 145, 31-40.

Droogers, P., Fermont, A. \& Bouma, J. 1996. Effects of ecological soil management on workability and trafficability of a loamy soil in the Netherlands. Geoderma, 73, 131-145.

FAO 2006. Guidelines for Soil Description, 4th edn. FAO, Rome.

FAO-UNESCO-ISRIC 1988. Revised Legend of the FAO-UNESCO Soil Map of the World. World Resources Report No 60, FAO, Rome.

Fendorf, S., La Force, M.J. \& Li, G. 2004. Temporal changes in soil partitioning and bioaccessibility of arsenic, chromium and lead. Journal of Environmental Quality, 33, 2049-2055.

FitzPatrick, E. 1970. A technique for the preparation of large thin sections of soils and unconsolidated material. In: Micromorphological Techniques and Applications (eds D.A. Osmond \& P. Bullock), pp. 3-13. Technical Monograph 2. Soil Survey of England and Wales, Lawes Agricultural Trust, Harpenden.

Flores, L., Blas, G., Hernández, G. \& Alcalá, R. 1997. Distribution and sequential extraction of some heavy metals from soils irrigated with waste water from Mexico City. Water, Air and Soil Pollution, 98, 105-117.

Haiyan, W. \& Stuantes, A.O. 2003. Heavy metal pollution in airwater-soil-plant system of Zhuzhou, Hunan Province, China. Water, Air and Soil Pollution, 147, 79-107.

Jacobson, A.R., Dousset, S., Andreux, F. \& Baveye, P.C. 2007. Electron microprobe and synchrotron X-ray fluorescence mapping of the heterogeneous distribution of copper in high-copper vineyard soils. Environmental Science and Technology, 41, 6343-6349.

Jones, S.D. \& Doner, H.E. 1998. X-ray Fluorescence Microprobe Analysis of a Contaminated Soil. Advanced Light Source (ALS) Compendium of User Abstracts [WWW document]. URL http://www-als.lbl. gov/als/compendium/AbstractManager/uploads/jones.pdf.

Jongmans, A.G., Pulleman, M.M. \& Marinissen, J.C.Y. 2001. Soil structure and earthworm activity in a marine silt loam under pasture versus arable land. Biology and Fertility of Soils, 33, 279 285.

Jongmans, A.G., Pulleman, M.M., Balabane, M., van Oort, F. \& Marinissen, J.C.Y. 2003. Soil structure and characteristics of organic matter in two orchards differing in earthworm activity. Applied Soil Ecology, 24, 219-232. 
Kretzschmar, R., Borkovec, M., Grolimund, D. \& Elimelech, M. 1999. Mobile subsurface colloids and their role in contaminant transport. Advances in Agronomy, 66, 121-193.

Labanowski, J., Sebastia, J., Foy, E., Jongmans, A.G., Lamy, I. \& van Oort, F. 2007. Fate of metal-associated POM in a soil under arable land use contaminated by metallurgical fallout in northern France. Environmental Pollution, 149, 59-69.

Lamy, I., van Oort, F., Dère, C. \& Baize, D. 2006. Use of major- and trace-element correlations to assess metal migration in sandy Luvisols irrigated with wastewater. European Journal of Soil Science, 57, 731-740.

Leguédois, S., van Oort, F., Jongmans, A.G. \& Chevallier, P. 2004. Morphology, chemistry and distribution of neoformed spherulites in agricultural land affected by metallurgical point-source pollution. Environmental Pollution, 130, 135-148.

Manceau, A., Lanson, B., Schlegel, M.L., Hargé, J.C., Musso, M., Eyberhard-Bérard, L. et al. 2000. Quantitative Zn speciation in smelter-contaminated soils by EXAFS spectroscopy. American Journal of Science, 300, 289-343.

Manceau, A., Marcus, M.A., Tamura, N., Proux, O., Geoffroy, N. \& Lanson, B. 2002. Quantitative speciation of heavy metals in soils and sediments by synchrotron X-ray techniques. In: Applications of Synchrotron Radiation in Low-Temperature Geochemistry and Environmental science (eds P.A. Fenter, M.L. Rivers, N.C. Sturchio \& S.R. Sutton), pp. 341-428. Mineralogical Society of America, Washington DC.

van Oort, F., Jongmans, A.G., Citeau, L., Lamy, I. \& Chevallier, P. 2006. Microscale $\mathrm{Zn}$ and $\mathrm{Pb}$ distribution patterns in subsurface soil horizons: an indication for metal transport dynamics. European Journal of Soil Science, 57, 154-166. van Oort, F., Labanowski, J., Jongmans, A.G. \& Thiry, M. 2007. Le devenir des polluants métalliques dans les sols: révélateur d'impacts de l'activité humaine sur la pédogenèse? Etude et Gestion des Sols, 14, 287-303.

Risler, E. 1897. Géologie Agricole, IV. Berger-Levrault Imprimerie, Nancy, France.

Sebastia, J., Labanowski, J. \& Lamy, I. 2007. Changes in soil organic matter chemical properties after organic amendments. Chemosphere, 68, 1245-1253.

Sebastia, J., van Oort, F. \& Lamy, I. 2008. Buffer capacity and Cu affinity of soil particulate organic matter (POM) size fractions. European Journal of Soil Science, 59, 304-314.

Six, J., Elliott, E.T., Paustian, K. \& Doran, J.W. 1998. Aggregation and soil organic matter accumulation in cultivated and native grassland soils. Soil Science Society of America Journal, 62, 13671377.

Stoops, G. 2003. Guidelines for Analysis and Description of Soil and Regolith Thin Sections. Soil Science Society of America Inc., Madison, WI.

Van Ranst, E. \& De Coninck, F. 2005. Evaluation of ferrolysis in soil formation. European Journal of Soil Science, 53, 513-519.

Védry, B., Gousailles, M., Affholder, M., Lefaux, A. \& Bontoux, J. 2001. From sewage water treatment to waste water reuse. One century of Paris sewage farms history. Water Science and Technology, 43, 101-107.

Wang, J.X., Piccot, D., Chevallier, P., Legrand, F. \& Abbas, K. 1993. VIRESYME: Logiciel d'exploitation des spectres de fluorescence $X$. Note CEA-N-2756, 231-235, CEA, Gif-sur-Yvette, France. 